\title{
Behavior affected by routine oxytocin injection in crossbred cows in the tropics
}

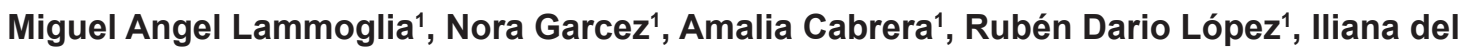 \\ Carmen Daniel Rentería ${ }^{1}$, Rebeca Rojas-Ronquillo
}

${ }^{1}$ Universidad Veracruzana, Facultad de Ciencias Biológicas y Agropecuarias, Tuxpan, Veracruz, México

\begin{abstract}
The objective of the study was to determine the effect of routine intramuscular injection of oxytocin to induce milk ejection on behavior assessed in terms of stress and rectal temperature in crossbred cows (Bos indicus $\times$ Bos taurus) in the tropics of Veracruz, México. Immediately after calving, cows were milked twice a day $(\mathrm{n}=210)$ and randomly assigned to receive at each milking: $10 \mathrm{IU}(0.5 \mathrm{~mL})$ of oxytocin intramuscularly $(\mathrm{n}=70) ; 0.5 \mathrm{~mL}$ of saline solution intramuscularly $(\mathrm{n}=70)$; or no injection $(\mathrm{n}=70)$. The following behavioral indicators of stress were observed: trampling, kicking, tail movement, failure to eat, jumping to avoid injection, vocalization, urination, and defecation. After milking, rectal temperature (RT) was measured. Statistical analysis was performed using ANOVA and chi-square. There were no differences in terms of behavioral stress indicators or rectal temperature in cows injected with oxytocin or saline solution, but both groups had greater behavioral indicators of stress and RT compared with non-injected cows. Cows injected with oxytocin or saline solution manifested a higher percentage of animals that trampled $(96.8 \%)$, kicked (32\%), ceased eating (61.2\%), moved the tail $(81.2 \%)$, jumped (20.9\%) and avoided the injection (78.2\%), compared with non-injected cows. Cows injected with oxytocin and saline solution had higher rectal temperature $\left(39.13 \pm 0.08{ }^{\circ} \mathrm{C}\right)$ compared with non-injected cows $\left(38.96 \pm 0.12{ }^{\circ} \mathrm{C}\right)$. All injected cows had higher behavioral indicators of stress measurements and rectal temperature regardless of the solution, suggesting that cows injected routinely and intramuscularly do not become habituated to this, even though some cows were injected more than 600 times throughout lactation.
\end{abstract}

Key Words: animal welfare, dairy cow, stress

\section{Introduction}

In recent years, animal welfare has become a very important topic in the livestock context (Grandin, 2014; Santurtun and Phillips, 2015; Scholten et al., 2013). Several publications show that adequate animal welfare makes them more productive (Callejo, 2009; de Vries et al., 2011). Kielland et al. (2010) found that farmers with empathy and a positive attitude towards livestock caused their dairy cows to manifest lower prevalence of skin lesions over the carpus. However, there are regions around the world where animal welfare is not an important issue for farmers. In developing countries in tropical regions, diverse production systems and lack of regulation lead to several problems such as poor animal welfare (McDermott et al., 2010).

\footnotetext{
Received August 19, 2015 and accepted April 4, 2016.

Corresponding author: rebrojas@uv.mx

http://dx.doi.org/10.1590/S1806-92902016000800008

Copyright (C) 2016 Sociedade Brasileira de Zootecnia. This is an Open Access article distributed under the terms of the Creative Commons Attribution License (http://creativecommons.org/licenses/by/4.0/), which permits unrestricted use, distribution, and reproduction in any medium, provided the original work is properly cited.
}

Milk production characteristics in these tropical regions are affected by local climate and economics: for instance, cattle with Bos indicus genetic influence abound due to their resistance to environmental conditions (Berman, 2011); owing to increasing demand for greater efficiency in livestock production, mechanical milking has increased exponentially and likewise exogenous application of oxytocin to induce milk ejection at milking (Bruckmaier et al., 1994; Garcez et al., 2013).

The practice of routinely injecting synthetic oxytocin to induce milk ejection has increased among dual-purpose cows in the tropical areas of México (Villa Godoy et al., 2003; Albarrán-Portillo et al., 2015). The use of oxytocin can improve milk ejection, especially in the case of those cattle farms where optimum milk production practices are lacking, for which milk production could be improved by up to $12 \%$ (Nostrand et al., 1991). Kaskous et al. (2006) reported that injecting $50 \mathrm{IU}$ of oxytocin increased milk collection by $58 \%$. While most farmers believe that the routine injection of oxytocin is harmless, Garcez et al. (2013) reported that these cows increased serum cortisol concentrations when injected, indicating animal response to stressful conditions. Animal behavior assessment can 
be used as an indicator of stress. Munksgaard et al. (2001) observed frequency of kicking, leg and tail movements and also defecation and urination during milking sessions, aiming to determine fear of humans.

The objective of this study was to determine the effects of routine intramuscular injection of oxytocin to induce milk ejection in assessment of behavioral stress and rectal temperature of crossbred (Bos indicus $\times$ Bos taurus) cows in the tropics.

\section{Material and Methods}

This study was carried out for livestock production in the region of Tihuatlán, Veracruz, México, located $60 \mathrm{~m}$ asl with an average annual temperature of $22{ }^{\circ} \mathrm{C}$, abundant rains in summer and early fall, and an average annual rainfall of 1,076 $\mathrm{mm}$. The management of the animals used in this investigation follows that defined by Sherwin et al. (2003); the University Animal Care and Use Committee approved animal procedures. Cows (Bos taurus $\times$ Bos indicus) were managed in an intensive rotational system on 70 ha and 53 divisions of tropical grass (Brachiaria brizantha), rotated to a different pasture every $24 \mathrm{~h}$, and also fed chopped Taiwan grass (Pennisetum purpureum Schum), orange silage, minerals, and fresh water ad libitum. Cows had access to trees which provided natural shade and open barns for artificial shade. Assessed cows included Bos indicus (Zebu) and Bos taurus (Brown Swiss and Holstein) crosses. Milk production per cow was measured twice daily using a Waikato milk meter jar. Cows produced $14.5 \pm 0.8 \mathrm{~L}$ daily. Cow parity was $3.5 \pm 1.5$ calvings. Three weeks prior to calving, cows were moved to a pasture next to the milking barn and fed $4 \mathrm{~kg}$ of commercial concentrate with $180 \mathrm{~g} \mathrm{~kg}^{-1}$ of crude protein. After calving, calves were taken from their dams.

After calving, all cows in the experiment were randomly assigned to receive at each milking $10 \mathrm{IU}(0.5 \mathrm{~mL})$ of oxytocin intramuscularly $(\mathrm{n}=70) ; 0.5 \mathrm{~mL}$ of saline solution intramuscularly $(\mathrm{n}=70)$; or no injection $(\mathrm{n}=70)$. Injections were performed using $3 \mathrm{~mL}$ disposable syringes and 18 gauge $\times 1.5$ ' long needles.

Cows were mechanically milked in a stanchion barn (capacity of six cows) twice daily (at $5.30 \mathrm{~h}$ and 14:30 h). Upon entering the milking parlor, cows were head-trapped. Facing the trap, cows were supplied using a feed trough from which they were fed during milking (commercial concentrate with $18 \%$ crude protein, $4 \pm 1 \mathrm{~kg} /$ cow/milking). Cows were tied at the hocks and routine milking began. Once the milking unit was connected, oxytocin and saline solution were injected once in the rump. The average time that cows were in the stanchion barn was $4.45 \pm 0.45 \mathrm{~min}$. Cows were injected twice a day, every day, during the entire lactation. Data were collected from the same cows every 21 days, from July to November (2013). Cows were in different lactation stages so as to cover the entire lactation.

A team of five technicians (two professors and three veterinary students) was divided into two groups of two people to collect stress indicators, and a person was allocated to film the milking cows to provide follow up data analysis. All technicians collected data $3 \mathrm{~m}$ away from the milking stanchion to avoid stress, using the same procedure for all cows, regardless of the groups. All technicians had preliminary training before data collection started.

Data collection initiated as soon as cows entered the stanchion barn and the milking procedure started, performed by direct observation and also by filming the cows during milking. During the milking procedure, behavioral indicators of stress were recorded according to Rousing et al. (2004) and collected as follows: whether a cow kicked and how many times it did so (kicking); trampling was considered as when a cow flexed or lifted one of its hooves and the times it repeated this were counted along with moving to avoid intramuscular rump injection, as well as whether the cow tried to step aside, bowed, or otherwise attempted to evade the injection; other considerations included whether the cow stopped eating or jumped in response to the injection; tail wagging and how many times; also urination and defecation. After milking, rectal temperature was measured using a digital thermometer (Microlife, MT200, Switzerland). Data collection was undertaken until cows left the stanchion barn.

Note: Cows in the treatment groups (oxytocin and saline solution) were injected an average of 610 times during lactation.

STATISTICA 7 software was used. ANOVA was performed using treatments, stage of lactation (number of days in milk), parity, and breed as independent variables and the dependent variable was the behavioral assessment of stress mentioned previously. Chi-square test was used to analyze frequencies of behavioral indicators of stress in each treatment. Variables defecation, urination, and vocalization were not considered in the statistical analysis because they did not appear often enough to compare the means between the three different groups. KolmogorovSmirnov and Levene tests were applied to check normal distribution and variance homogeneity of the data. 


\section{Results}

Behavioral assessment of the stress expressed by cows was not affected by the number of days in milk ( $P>0.5$, by ANOVA test). Cows responded similarly to the injections from the beginning of lactation until the end, indicating failure to become habituated to the intramuscular injection.

Cows injected intramuscularly with either oxytocin or saline solution moved more to avoid the injection, compared with non-injected cows $(\mathrm{P}<0.05)$ (Table 1). Likewise, other behavioral stress indicators such as tail wagging, trampling, kicking, ceasing to eat, and jumping increased among cows injected with oxytocin and saline solution compared with non-injected cows $(\mathrm{P}<0.05)$ (Table 1$)$.

There was a treatment $\times$ parity interaction $(\mathrm{P}<0.05)$ in which primiparous cows injected with oxytocin or saline solution trampled more times $(4.4 \pm 0.48)$ than multiparous cows (1.1 \pm 0.54$)$ (Figure 1).

The maximum and minimum temperatures observed throughout the study were $41.4{ }^{\circ} \mathrm{C}$ and $37.6{ }^{\circ} \mathrm{C}$, respectively. Cows injected with oxytocin or saline solution had similar rectal temperatures $\left(39.13 \pm 0.08{ }^{\circ} \mathrm{C}\right)$ $(\mathrm{P}<0.10)$, but these were higher than non-injected cows $\left(38.96 \pm 0.12{ }^{\circ} \mathrm{C}\right)(\mathrm{P}<0.05)$. There was also an interaction
$(\mathrm{P}<0.05)$ between treatment and parity, in which injected multiparous cows (oxytocin or saline solution) had higher rectal temperatures $\left(39.20 \pm 0.12{ }^{\circ} \mathrm{C}\right)$ compared with injected primiparous cows $\left(39.06 \pm 0.16{ }^{\circ} \mathrm{C}\right)$; however, both groups had higher rectal temperatures than non-injected cows $\left(38.98 \pm 0.17^{\circ} \mathrm{C}\right.$ for primiparous and $38.94 \pm 0.18^{\circ} \mathrm{C}$ for multiparous) (Figure 2).

\section{Discussion}

The routine intramuscular injection of oxytocin or saline solution increased all behavioral stress indicators and interrupted the classical definition of animal welfare (von Keyserlingk et al., 2009). Callejo (2009) proposed that animal welfare indicates the perfect harmony of the animal with the surrounding environment, whereas von Keyserlingk et al. (2009) pointed out that animal welfare involves not only biological functional aspects, but also affective states such as pain that need to be taken into consideration. In this case, cows being injected intramuscularly at milking with either oxytocin or saline solution were not in complete harmony with the environment during milking, and clearly experienced pain, leading them to a stressful state.

Several authors describe behavioral manifestations, such as trampling, kicking, ceasing to eat, and tail wagging,

Table 1 - Typical behavioral stress indicators among dairy cows in the tropics of Veracruz, México, following intramuscular injection of oxytocin to induce milk ejection $(\mathrm{n}=210)$

\begin{tabular}{lcc}
\hline Behavioral measures of stress & Cows injected with oxytocin & Cows injected with saline solution \\
\hline Avoiding injection & $78.6 \% \mathrm{a}$ & $80.0 \% \mathrm{a}$ \\
Tail wagging & $81.4 \% \mathrm{a}$ & $80.0 \% \mathrm{a}$ \\
Trampling & $97.1 \% \mathrm{a}$ & $95.7 \% \mathrm{a}$ \\
Kicking & $31.4 \% \mathrm{a}$ & $3.3 \% \mathrm{~b}$ \\
Stopping eating & $61.4 \% \mathrm{a}$ & $0 \% \mathrm{~b}$ \\
Jumping & $21.4 \% \mathrm{a}$ & $62.8 \% \mathrm{a}$ \\
\hline
\end{tabular}

$\mathrm{a}, \mathrm{b}$ - values followed by different letters differ $(\mathrm{P}<0.05)$ by Chi-square test.



Statistical analysis by ANOVA test.

Figure 1 - Trampling time periods (columns represent means and error bars the standard deviation) observed among injected or non-injected and either primiparous or multiparous cows, during milking.

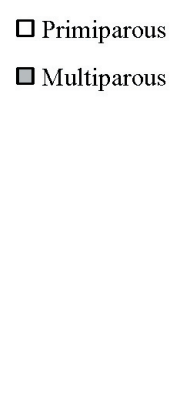

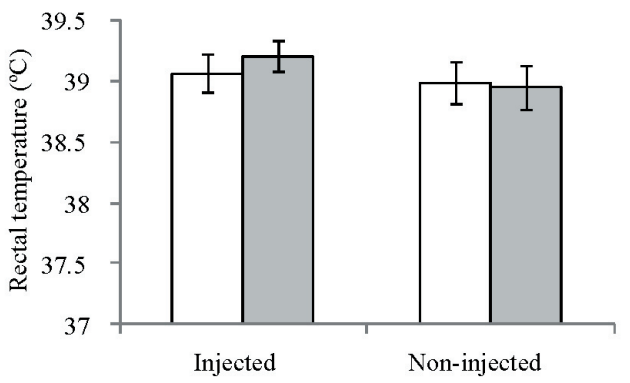

Statistical analysis by ANOVA test.

Figure 2 - Rectal temperature $\left({ }^{\circ} \mathrm{C}\right.$, columns represent means and error bars the standard deviation) observed among injected or non-injected and either primiparous or multiparous cows, during milking. 
as stress indicators (Stott, 1981; Munksgaard et al., 2001; Rushen et al. 2001; Wenzel et al., 2003; Rousing et al., 2004). Wenzel et al. (2003) concluded that cows that kicked and trampled during milking increased their heart rate as well as milk cortisol concentrations, thus considering these parameters as signs of stress. However, behavioral responses are not always caused by stress; other aspects can cause changes in behavior (hunger, disease, etc.).

The injection process affected behavioral indicators observed in this study: thus, cows injected intramuscularly with saline solution or oxytocin showed an increase in all these indicators compared with non-injected cows.

Primiparous cows injected with oxytocin and saline solution manifested a greater increase in behavioral stress indicators compared with multiparous cows that were also injected. These reactions are similar to those reported by Jacobs and Siegford (2012), who reported that primiparous cows under stress in the milking parlor trampled and kicked more than adult cows under the same stressful conditions.

Cows injected with either saline solution or oxytocin also showed an increase in rectal temperature. This increase in rectal temperature appears to result from increased physical activity among these cows (kicking, trampling, wagging their tails, etc. (Spiers et al., 2001)). However, Lusk (1989) reported that, in certain stressful situations, there is another component called stress-induced hyperthermia, related to the activity of the sympathetic-adenomedular system and hypothalamic-pituitary-adrenocortical axis. This hyperthermia is considered to constitute an early response to an unpleasant situation that may or may not have been identified, which may also explain why cows injected intramuscularly with saline solution or oxytocin had an increase in rectal temperature.

\section{Conclusions}

The routine intramuscular injection of oxytocin to induce milk ejection has a negative effect on behavioral stress indicators and on rectal temperature of crossbred cows in the tropics. Cows do not habituate to the injection of either oxytocin or saline solution, showing a clear decline in wellbeing. We propose that positive stimuli should be employed to induce milk ejection, while avoiding oxytocin injection as much as possible.

\section{References}

Albarrán-Portillo, B.; Rebollar-Rebollar, S.; García-Martínez, A.; Rojo-Rubio, R.; Avilés- Nova, F. and Arriaga-Jordán, C. M. 2015.
Socioeconomic and productive characterization of dual-purpose farms oriented to milk production in a subtropical region of Mexico. Tropical Animal Health and Production 47:519-523.

Berman, A. 2011. Invited review: Are adaptations present to support dairy cattle productivity in warm climates? Journal of Dairy Science 94:2147-2158.

Bruckmaier, R. M.; Schams, D. and Blum, J. W. 1994. Continuously elevated concentrations of oxytocin during milking are necessary for complete milk removal in dairy cows. Journal of Dairy Research 61:323-334

Callejo, R. A.2009. Cow Comfort "El bienestar de la vaca lechera". Editorial SERVET, España.

de Vries, M.; Bokkers, E. A. M.; Dijkstra, T.; van Schaik, G. and de Boer, I. J. M. 2011. Invited review: Associations between variables of routine herd data and dairy cattle welfare indicators. Journal of Dairy Science 94:3213-3228.

Garcez, N.; Domínguez, B.; Ángeles, A. A.; Torres, H.; Alarcón, M. A.; Daniel, I. C. and Lammoglia, M. A. 2013. Concentraciones de cortisol y producción láctea en vacas deordeño inyectadas con oxitocina en el trópico veracruzano. p.246. In: Proceedings of the 16th Latin American Congress Buiatrics. Ecuadorian Association Buiatrics, Quito, Ecuador.

Grandin, T. 2014. Animal welfare and society concerns finding the missing link. Meat Science 98:461-469

Jacobs, J. A. and Siegford, J. M. 2012. Lactating dairy cows adapt quickly to being milked by an automatic milking system. Journal of Dairy Science 95:1575-1584.

Kaskous, S. H.; Weiss, D.; Massri, Y.; Al-Daker, A-M. B.; Nouh, A-D. and Bruckmaier, R. M. 2006. Oxytocin release and lactation performance in Syrian Shami cattle milked with and without suckling. Journal of Dairy Research 73:28-32.

Kielland, C.; Skjerve, E.; Østerås, O. and Zanella, A. J. 2010. Dairy farmer attitudes and empathy toward animals are associated with animal welfare indicators. Journal of Dairy Science 93:2998-3006.

Lusk, R. H. 1989. Thermoregulation. p.23-27. In: Textbook of veterinary internal medicine. Ettinger, S. J., ed. W. B. Saunders, Philadelphia.

Nostrand, S. D.; Galton, D. M.; Erb, H. N. and Bauman, D. E. 1991. Effects of daily exogenous oxytocin on lactation milk yield and composition. Journal of Dairy Science 74:2119-2127.

McDermott, J. J.; Staal, S. J.; Freeman, H. A.; Herrero, M. and Van de Steeg, J. A. 2010. Sustaining intensification of smallholder livestock systems in the tropics. Livestock Science 130:95-109.

Munksgaard, L.; De Passillé, A. M.; Rushen, J.; Herskin, M. S. and Kristensen, A. M., 2001. Dairy cows' fear of people: social learning, milk yield and behaviour at milking. Applied Animal Behaviour Science 73:15-26.

Rousing, T.; Bonde, M.; Badsberg, J. H. and Sorensen, J. T. 2004 Stepping and kicking behaviour during milking in relation to response in human-animal interaction test and clinical health in loose housed dairy cows. Livestock Production Science 88:1-8.

Rushen, J.; Munksgaard, L.; Marnet, P. G. and DePassillé, A. M. 2001. Human contact and the effects of acute stress on cows at milking. Applied Animal Behaviour Science 73:1-14.

Santurtun, E. and Phillips, C. J. C. 2015. The impact of vehicle motion during transport on animal welfare. Research in Veterinary Science 100:303-308.

Scholten, M. C. T.; de Boer, I. J. M.; Gremmen, B. and Lokhorst, C. 2013. Livestock Farming with Care: towards sustainable production of animal-source food, NJAS-Wageningen Journal of Life Sciences 66:3-5.

Sherwin, C. M.; Christiansen, S. B.; Duncan, I. J.; Erhard, H.; Lay, D.; Mench, J.; O'Connor, C. and Petherick, C. 2003. Guidelines for the ethical use of animals in applied animal behaviour research. Applied Animal Behaviour Science 81:291-305.

Spiers, D. E.; Spain, J. N.; Leonard, M. J. and Lucy, M. C. 2001. Effect of cooling strategy on dairy cow performance during heat stress. p.45-55. In: Livestock Environment VI: Proceedings of the 6th 
International Symposium. Stowell, R. R.; Bucklin, R.; Bottcher, R. W., eds. ASAE (Pub. 701P0201), St. Joseph, Michigan.

Stott, G. H. 1981. What is animal stress and how is it measured? Journal of Animal Science 52:150-153.

von Keyserlingk, M. A. G.; Rushen, J.; De Passillé, A. M. and Weary, D. M. 2009. Invited review: The welfare of dairy cattle Key concepts and the role of science. Journal of Dairy Science 92:4101-4111.
Villa Godoy, A.; González Padilla, E. and Ortiz Díaz, R. 2003. Oxitocina y somatotropina como método para incrementar la producción en ganado de trópico. In: Proceedings of the 17th National Congress Buiatrics. Villahermosa, Tabasco, México.

Wenzel, C.; Schonreiter-Fischer, S. and Unshelm, J. 2003. Studies on step- kick behavior and stress of cows during milking in and automatic milking system. Livestock Production Science $83: 237-246$ 